\title{
DEFENCE-RELATED ENZYMES IN PEPPER ROOTS DURING INTERACTIONS WITH ARBUSCULAR MYCORRHIZAL FUNGI AND/OR Verticillium dahliae
}

Garmendia López, I. (*), Aguirreolea Morales, J., Sánchez-Díaz, M. and Goicoechea Preboste, N. Departamento de Biología Vegetal. Facultades de Ciencias y Farmacia. University of Navarra.

c/Irunlarrea s/n. 31008-Pamplona

${ }^{(*)}$ Present address: Dpto. Ciencias de la Tierra y del Medio Ambiente. Facultad de Ciencias. University of Alicante. Apto de correos, 99. 03080-Alicante

INTRODUCTION
The active defence responses of plants include
the activation of genes that are coding for
enzymes of the phenylpropanoid pathway or for
pathogenesis-related (PR) proteins, some of
them with chitinase, chitosanase and $\beta-1,3-3$
glucanase activities (Pozo et al., 2002) that
degrade wall of many pathogenic fungi (Van
Loon and Van Strien, 1999).
Previous studies have described that the
arbuscular mycorrhizal fungus (AMF) Glomus
deserticola (Trappe, Bloss and Menge) can
reduce the deleterious effect of Verticillium
dahliae Kleb. on Capsicum annuum L. cv. Piquillo
growth and yield (Garmendia et al., 2004). The
establishment of the mycorrhizal association
involves the production of plant defence related
proteins that could contribute to the
bioprotection (Lambais, 2000).
Our first objective was to study if $V$. dahliae
induced defence mechanisms in roots before
infected-pepper developed visible symptoms of
disease. The second aim was to determine if
AMF induced defence-related enzymatic activities
in pepper roots before or after pathogen's
attack.

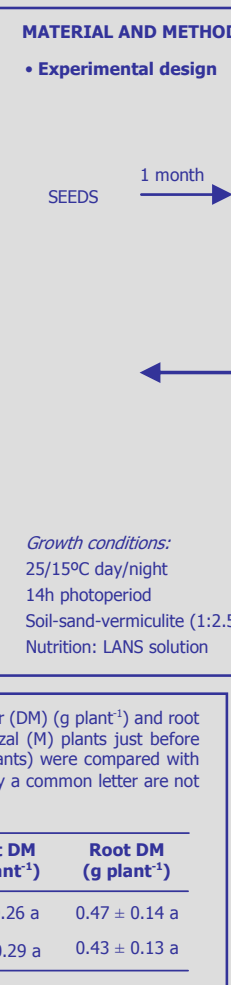

Table 1. Mycorrhizal colonization (\%), shoot dry matter (DM) $\left(\mathrm{g} \mathrm{plant}^{-1}\right)$ and root DM ( $g$ plant $\left.{ }^{-1}\right)$ in non-mycorrhizal $(\mathrm{NM})$ and mycorrhizal (M) plants just before

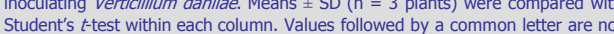
Student's $t$-test within each colum
significantly different $(p \leq 0.05)$.

\begin{tabular}{lccc}
\hline Treatments & $\begin{array}{c}\text { Mycorrhizal colonization } \\
(\%)\end{array}$ & $\begin{array}{c}\text { Shoot DM } \\
\text { (g plant }^{-1} \text { ) }\end{array}$ & $\begin{array}{c}\text { Root DM } \\
\text { (g plant }^{-1} \text { ) }\end{array}$ \\
\hline NM & - & $0.87 \pm 0.26 \mathrm{a}$ & $0.47 \pm 0.14 \mathrm{a}$ \\
M & $25.32 \pm 6.76$ & $0.90 \pm 0.29 \mathrm{a}$ & $0.43 \pm 0.13 \mathrm{a}$ \\
\hline
\end{tabular}
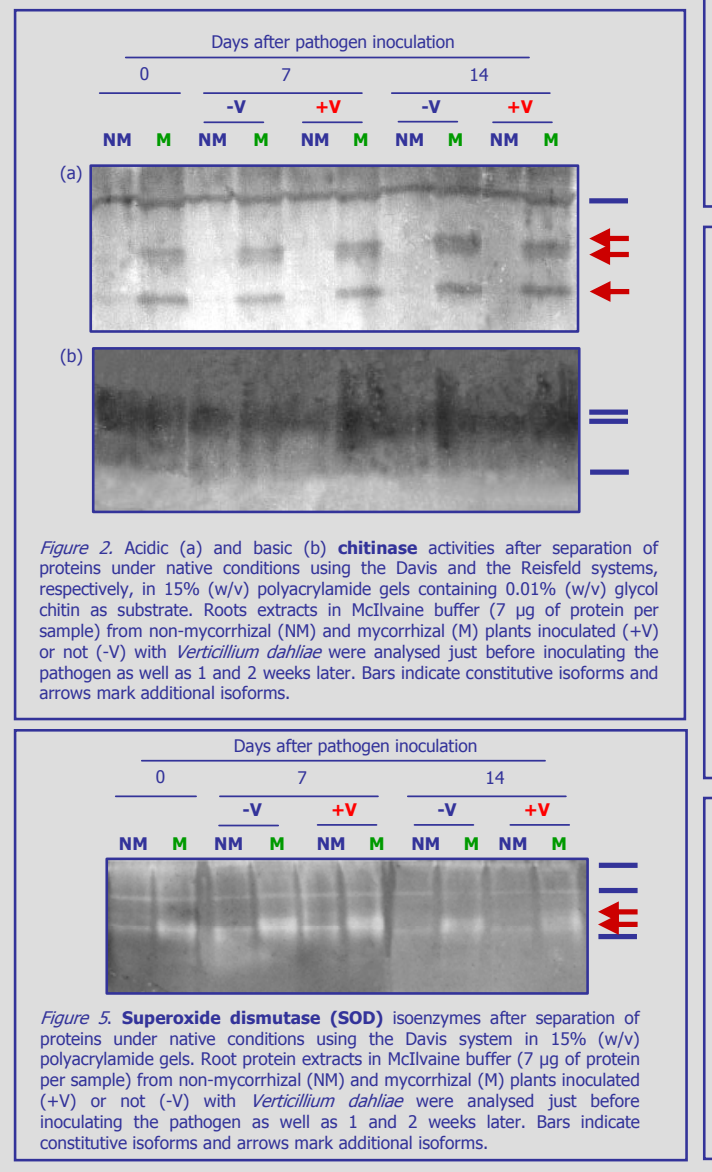

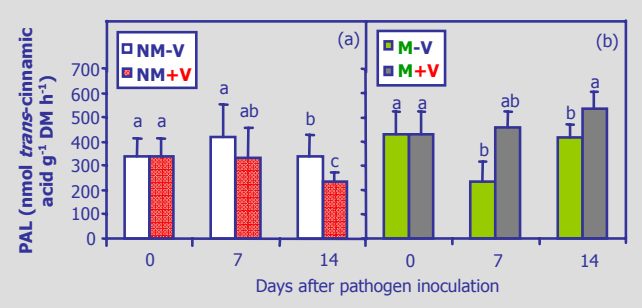

Figure 1. Phenylalanine ammonia-lyase (PAL) activities (nmol transcinnamic acid $\mathrm{g}^{-1}$ DM $\mathrm{h}^{-1}$ ) in roots from non-mycorrhizal (NM) (a) and mycorrhizal (M) (b) plants inoculated $(+\mathrm{V})$ or not $(-\mathrm{V})$ with Verticillium dahliae. Means $\pm \mathrm{SD}(\mathrm{n}=3$ plants) just before inoculating Verticillium were compared with Student's $t$-test and data on days 7 and 14 after pathogen inoculation were analysed by Tukey-b-test. Histograms followed by a
common letter are not significantly different $(p<0.05)$. PAL activities were common letter are not significantly different $(p \leq 0.05)$. PAL acti
assayed according to Dunn et al. (1998) with slight modifications.

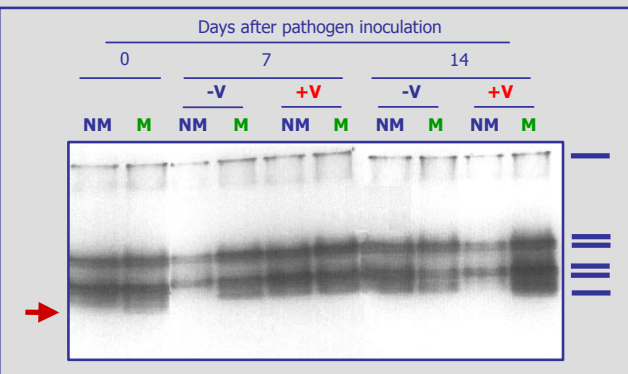

Figure 4. Peroxidase activity after separation of proteins under native conditions using the Davis system in $15 \%(\mathrm{w} / \mathrm{v})$ polyacrylamide gels. Root protein extracts in McIlvaine buffer ( $7 \mu \mathrm{g}$ of protein per sample) from nonmycorrhizal (NM) and mycorrhizal (M) plants inoculated $(+V)$ or not $(-V)$ with Verticillium dahliae were analysed just before inoculating the pathogen as well as 1 and 2 weeks later. After protein separation, gels were incubated in $0.1 \mathrm{M}$
Tris- $\mathrm{HCl}\left(\mathrm{pH}\right.$ 7.6) with 4-chloro-1-naphthol and $\mathrm{H}_{2} \mathrm{O}_{2}$. Bars indicate
. constitutive isoforms and arrows mark additional isoforms.

\begin{tabular}{l} 
CONCLUSIONS \\
isoforms of acidic chitinases and SOD \\
together with enhanced PAL and peroxidase \\
activities two weeks after pathogen \\
inoculation could be involved in the biocontrol \\
of Verticillium-induced wilt in pepper (C. \\
annuum L. Cv. Piquillo) by Glomus deserticola. \\
perticillium dahliae neither stimulated the \\
phenylpropanoid pathway nor elicited \\
hydrolytic activities in non-mycorrhizal pepper \\
roots one and two weeks after its inoculation. \\
No signal corresponding to chitosanase \\
activity was detected in any treatment. \\
\hline
\end{tabular}
ACKNOWLEDGEMENTS The authors are grateful to the Estacion Experimental del Zaidin (CSIC, Granada) and, Aguilar, Dr. R. Calvente. Fundación Universitaria de Navarra (FUNA) and Gobierno Vasco (AE-2000) supported this work.

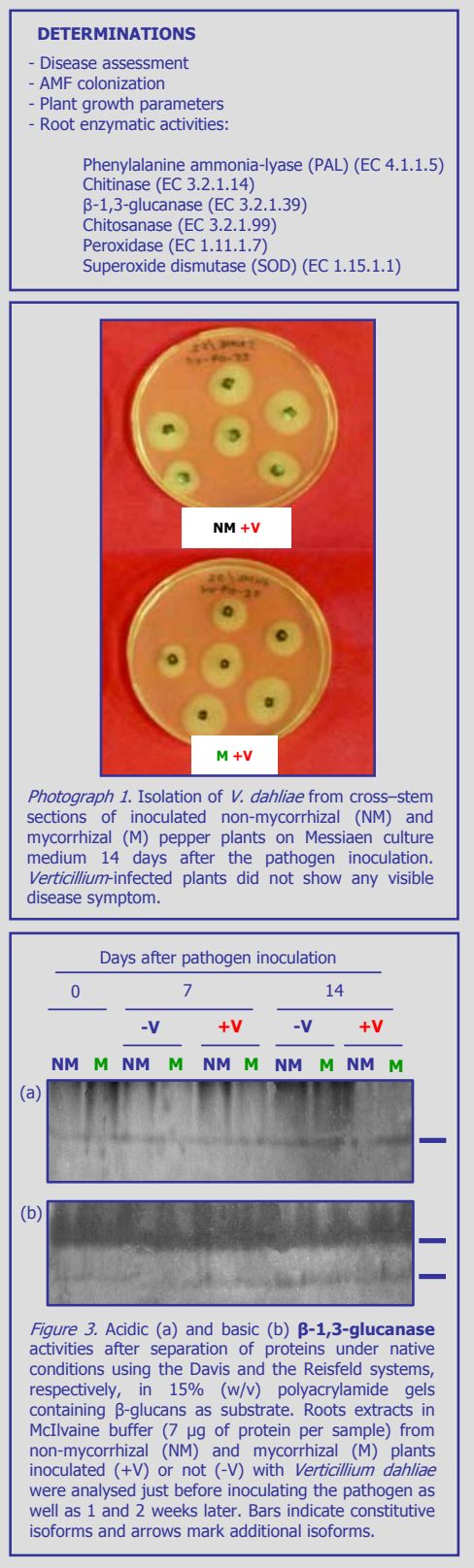

REFERENCES

Davis BJ (1964) Disc electrophoresis. II. Method and
application to human serum proteins. Ann. NY Acad. Sci. 121: 404Dunn DC, Duncan LW and Romeo JT (1998) Changes in

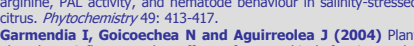
Garmendia I, Goicoechea $\mathrm{N}$ and Aguirreolea J (2004) Plant
phenology influences the effect of mycorrizizal fungi on the development of Verticilium-induced wilt in pepper. Eur. J. Pla ambais MR (2000) Regulation of plant defense-related genes arbuscular mycorrhizae. In: GK Podila and DD Douds (eds), Current
Advances in mycorrhizae Research. APS Press, Minnesota, USA, Pozo MJ, Slezack-Deschaumes S, Dumas-Gaudot E,
Gianinazzi S and Azcó-Aguilar C' (2002) Plant defense responses induced by arbuscular mycorrhizal fungi. In: $\mathrm{S}$
Gianinazzi, $\mathrm{H}$ Schüepp, JM Barea and $\mathrm{K}$ Haselwandter (eds), Mycorrhizal Technology in Agriculture. From Genes to Bioproducts. Reisfeld RA, Lewis, VJ and Williams DE (1962) Disk
Ro gels. Nature 195: 281-283. pathogenesis-related proteins, their activities, and comparative
analysis of PR-1 type protein. Physiol. Mol, Plant Pathol. 55: 85-97.2 